\title{
PENGARUH KEPEMIMPINAN TERHADAP KINERJA PERAWAT DI RUANG PERAWATAN KELAS III RUMAH SAKIT HUSADA JAKARTA
}

\author{
Ria Efkelin Mose ${ }^{1)}$ \\ ${ }^{1)}$ Sekolah Tinggi Ilmu Kesehatan RS Husada, Jakarta Pusat, 10730, Indonesia \\ e-mail: ria_efkelin@stikesrshusada.ac.id
}

\begin{abstract}
ABSTRAK
Kepemimpinan yang baik di Rumah Sakit akan meningkatkan kinerja perawat. Kinerja perawat yang baik dapat meningkatkan kualitas pelayanan kepada pasien. Penelitian ini dilakukan untuk mengetahui pengaruh kepemimpinan terhadap kinerja perawat pada Rumah Sakit Husada Jakarta dengan jumlah sampel sebanyak 47 perawat yang bekerja di ruang Melati. Analisis yang digunakan meliputi uji validitas, uji reliabilitas, uji asumsi klasik, uji korelasi dan uji regresi baik secara sederhana maupun secara simultan dengan pengolahan datanya menggunakan metode statistik. Hasil analisis penelitian sederhana menunjukan bahwa kontribusi kepemimpinan dianggap penting dan berpengaruh signifikan dalam meningkatkan kinerja perawat yaitu sebesar 91.3\%, sedangkan sisanya sebesar $8.7 \%$ dijelaskan oleh variabel lain yang tidak diteliti. Kepemimpinan yang tepat bagi institusi pelayanan kesehatan diharapkan mampu meningkatkan kinerja perawat sehingga pelayanan kesehatan dapat diberikan dengan optimal.
\end{abstract}

Kata kunci: Kepemimpinan; Kinerja; Perawat.

\begin{abstract}
Good leadership in the hospital will improve nurse performance. Performance of nurses can improve services quality to patients This study was conducted to determine the influence of leadership on the performance of nurses at Husada hospital with a total sample of 47 nurses working in Melati Room. The analysis used include validity, reliability test, classical assumption test, correlation and regression testing either partially or simultaneously with the processing of the statistical analysis. Results of the analysis showed that simple leadership is considered an important contribution and a significant effect in improving the performance of nurses in the amount of $91.3 \%$, while the remaining $8.7 \%$ is explained by other variables not examined. The right leadership for health service institutions is expected to be able to improve the performance of nurses so that health services can be provided optimally.
\end{abstract}

Keywords: Leadership; Nurses; Performance.

Jurnal Kesehatan Holistic/ Volume 4/ Nomor 1/Januari 2020

(ISSN: 2548-1843, EISSN: 2621-8704) 


\section{PENDAHULUAN}

Rumah Sakit merupakan tempat terjadinya hubungan kerjasama antara dokter, perawat dan tim kesehatan lainnya untuk membantu dalam kesembuhan pasien-pasien, khususnya untuk perawat yang sangat berperan penting dalam pencapaian kesembuhan yang diinginkan pasien, karena perawat adalah orang yang selalu mendampingi pasien dalam pemenuhan kebutuhan pasien secara biopsikospiritual selama 24 jam penuh. Salah satu faktor dapat meningkatkan kinerja pegawai adalah kepemimpinan karena dengan pemimpin yang mempunyai pandangan ke depan, mempunyai integritas yang tinggi dan semangat dalam bekerja serta melatih stafnya untuk terampil maka kinerja pegawai dapat meningkat. Untuk membawa bawahan sesuai dengan kemauan pemimpin, maka seorang pemimpin harus mampu memotivasi pegawai.

Motivasi ini dapat dilakukan dengan berbagai cara, antara lain memberikan pujian, memberikan penghargaan, memberikan insentif kepada pegawai yang mempunyai kinerja yang baik. Pada akhirnya kinerja sebuah organisasi masih tetap tergantung pada kualitas sumber daya manusia yang ada pada organisasi tersebut. Kualitas sumber daya manusia dipengaruhi oleh faktor-faktor antara lain tingkat pendidikan, pengalaman kerja, dan pernah tidaknya mengikuti kegiatan pelatihan dan pengembangan. Semakin tinggi tingkat pendidikan seseorang diharapkan semakin tinggi kinerjanya. Semakin banyak pengalaman kerja seseorang, juga semakin baik kinerjanya. Demikian juga semakin sering seseorang diikutkan kegiatan pelatihan dan pengembangan, maka ia akan semakin berkualitas, sehingga akan semakin baik pula kinerjanya.

Namun di lapangan ditemukan masih ada pemimpin kadang mendahului kepentingan pribadinya yang membuat dirinya kurang berani untuk melakukan supervisi bawahannya dalam bekerja, dan kurang memotivasi bawahannya dalam bekerja sehingga, bawahan yang kerja kurang teliti bisa sewaktu-waktu bekerja membuat kesalahan. 
Penelitian yang dilakukan oleh Nugrahaeni (2005) tentang Hubungan Gaya Kepemimpinan dengan Kinerja Pegawai di Biro Kredit Bank Indonesia. Gaya kepemimpinan memiliki pengaruh positif dan signifikan terhadap kinerja karyawan Biro Kredit Bank Indonesia dengan nilai koefisien korelasi 0,494 dan koefisien determinasi $24,4 \%$ yang dijelaskan melalui persamaan regresi $Y=43,368+0,472 X$. Berbeda dengan penelitian-penelitian sebelumnya penelitian ini mencari hubungan antara kepemimpinan dengan kinerja perawat. Tujuan penelitian ini adalah untuk mengetahui hubungan antara kepemimpinan dengan kinerja perawat di RS Husada.

\section{METODE}

Desain penelitian ini penulis menggunakan metode deskriptif kuantitatif untuk metode ilmiah yang digunakan dalam penelitian ini dapat dilaksanakan dengan relatif mudah dan terarah dan metode riset korelasi (correlation study) yakni penelitian yang dirancang untuk menentukan tingkat hubungan variabel-variabel yang berbeda dalam suatu populasi dengan jumlah responden 47 perawat. Dalam hal ini penulis dapat mengetahui berapa besar kontribusi variabel-variabel terhadap variabel terikatnya serta besarnya arah hubungan yang terjadi. Desain penelitian berdasarkan tujuannya adalah mendeskripsikan karakteristik suatu obyek yang dalam hal ini akan diperoleh gambaran tentang hubungan antara Pengaruh Kepemimpinan terhadap Kinerja Perawat di Ruang Perawatan Kelas III RS Husada.

\section{HASIL DAN PEMBAHASAN}

Hasil penelitian yang dilakukan didapatkan data mengenai distribusi responden berdasarkan berdasarkan jenis kelamin, umur, tingkat pendidikan dan masa kerja. Keempat aspek demografi tersebut mempunyai peran penting dalam menilai kinerja perawat di Rumah Sakit Husada Jakarta.

Hasil identifikasi dari menurut jenis kelamin didapatkan data secara umum dapat memberikan perbedaan pada perilaku dan kepribadian seseorang. 
Dalam suatu bidang pekerjaan jenis kelamin seringkali dapat menjadi pembeda aktivitas yang dilakukan oleh individu. Perbedaan kepribadian yang mendasar antara laki-laki dan perempuan. Laki-laki pada umumnya bersifat individualis, agresif, kurang sabar, lebih tegas, rasa percaya diri lebih tinggi dan lebih menguasai pekerjaan sedangkan perempuan cendrung lebih perhatian kepada orang lain, penurut, pasif, lebih mengkedepankan perasaan dan mempunyai tanggung jawab mengurus keluarga yang lebih besar dari pada laki-laki. Komposisi responden berdasarkan jenis kelamin di ruang Melati pada Rumah Sakit Husada Jakarta dapat dilihat pada Tabel 1 sebagai berikut :

Tabel 1

Distribusi Responden Berdasarkan Jenis Kelamin ( $\mathrm{n}=47)$

\begin{tabular}{llll}
\hline & & Frequency & Percent \\
\hline Valid & Laki-laki & 3 & 6.4 \\
& Perempuan & 44 & 93.6 \\
& Total & 47 & 100.0 \\
\hline
\end{tabular}

Sumber: Hasil Pengolahan Data Kuesioner
Berdasarkan Tabel 1 di atas nampak sebagian besar responden adalah perempuan yaitu sebanyak 44 responden atau sebesar $83.6 \%$, sedangkan responden laki-laki adalah sebanyak 3 responden atau sebesar 6.4\%. Hal ini mengindikasikan bahwa jumlah perawat perempuan lebih dominan dari pada perawat laki-laki. Fenomena ini sesuai kebijakan yang diterapkan Rumah Sakit Husada Jakarta, dimana perawat perempuan cenderung bersikap dan berlaku sesuai atau sejalan dengan kebijakan dan peraturan yang diterapkan Rumah Sakit Husada Jakarta

Hasil penelitian terkait umur responden didapatkan data: Kedewasaan seseorang dapat dilihat dari usia seseorang yang merupakan salah satu faktor yang akan mempengaruhi kemampuan, pengetahuan, tanggung jawab seseorang dalam bertindak, berpikir serta mengambil keputusan. Perawat yang lebih tua lebih berpengalaman dalam berpikir dan bertindak serta lebih terbiasa menghadapi persoalan yang muncul ditempat kerja, sehingga 
mereka telah terbiasa dan lebih mampu melakukan adaptasi dengan permasalahan yang muncul ditempat kerja, sehingga pengambilan keputusan cenderung lebih efektif ketimbang karyawan yang berusia muda, sebagaimana nampak dalam Tabel 2

Tabel 2

Distribusi Responden Berdasarkan Umur $(n=47)$

\begin{tabular}{llll}
\hline & Frequency & Percent \\
\hline Valid & $20-30$ Tahun & 33 & 70.2 \\
& $31-40$ Tahun & 5 & 10.6 \\
$41-50$ Tahun & 9 & 19.1 \\
$>$ 50 Tanun & 0 & 0 \\
Total & 47 & 100.0 \\
\hline
\end{tabular}

Sumber: Hasil Pengolahan Data Kuesioner

Pada tabel 4.2 di atas dapat dilihat bahwa jumlah responden yang berusia antara 20 sampai 30 tahun sebanyak 33 responden atau $70.2 \%$, berusia antara 30 sampai 40 tahun sebanyak 5 responden atau $10.6 \%$, berusia antara 41 sampai 50 tahun sebanyak 9 responden atau $19.1 \%$ dan yang berusia lebih dari 50 tahun sebanyak 0 responden atau $0.0 \%$.
Dilihat dari umur perawat yang bekerja di ruang Melati pada Rumah Sakit Husada sebagian besar adalah berusia antara 20 sampai 30 tahun, ini menunjukan bahwa dalam menjalankan aktivitas Rumah Sakit Husada lebih mengutamakan perawat dengan umur yang relatif masih muda karena mempunyai kemampuan fisik yang lebih baik dan lebih mampu melakukan adaptasi dengan permasalahan yang muncul ditempat kerja.

Pendidikan terakhir mempengaruhi kemampuan, wawasan dan tingkat kepercayaan diri dari responden dalam melaksanakan pekerjaannya. Hal tersebut dikarenakan pendidikan sangat penting guna meningkatkan kemampuannya.

Responden dengan tingkat pendidikan yang tinggi mampu bekerja dengan tingkat kesulitan dan tanggung jawab yang lebih tinggi dari pada perawat dengan tingkat pendidikan yang lebih rendah karena mereka lebih dipercaya untuk menangani tingkat pekerjaan yang dianggap tidak mampu 
dikerjakan oleh perawat yang kurang pengalaman. Komposisi responden berdasarkan aspek pendidikan terakhir dapat dilihat pada Tabel 3

Tabel.3

Distribusi Responden Berdasarkan Tingkat Pendidikan $(\mathrm{n}=47)$ Frequency Percent

\begin{tabular}{lcl}
\hline SPK / SPR & 1 & 2.1 \\
D3 Keperawatan & 46 & 97.9 \\
S1 Keperawatan & 0 & 0.0 \\
S2 Keperawatan & 0 & 0.0 \\
Total & 47 & 100.0 \\
\hline
\end{tabular}

Pada tabel 4.3 di atas dapat dilihat bahwa jumlah responden yang tingkat pendidikan SPK /SPR sebanyak 1 responden atau sebesar $2.1 \%$, pendidikan D3 Keperawatan sebanyak 46 responden atau $97.9 \%$, sedangkan tingkat pendidikan S1 Keperawatan dan pendidikan S2 Keperawatan sebanyak 0 responden atau $0.0 \%$.

Rumah Sakit Husada sebagian besar perawatnya berpendidikan menengah (D3 keperawatan), hal ini diperlukan karena perawat harus mempunyai kompetensi di bidangnya, harus mampu menolong pasien dan cepat dalam mengambil tindakan serta tanggung jawab yang tinggi atas pekerjaannya.

Masa kerja sangat memengaruhi penguasaan rincian pekerjaan dari seorang perawat, dimana responden dengan masa kerja yang lebih lama mempunyai pengalaman, kepercayaan diri dan penguasaan job description yang lebih baik. Kemampuan, pengetahuan, tanggung jawab dalam bertindak, berpikir serta mengambilan keputusan juga dipengaruhi oleh masa kerja, disamping usia perawat. Faktor usia dan pengalaman kerja saling terkait, dimana keduanya mempengaruhi kemampuan perawat dalam menghadapi persoalan dan mengambil keputusan. Perawat yang memiliki masa kerja yang lebih lama, cendrung lebih memahami struktur harapan-imbalan yang berlaku di Rumah Sakit Husada, sehingga mereka memiliki prilaku yang lebih efektif daripada perawat yang kurang berpengalaman. Dikarenakan hal-hal tersebut maka masa kerja merupakan bagian dari gambaran umum responden penelitian ini. 
Profil responden menurut masa kerja sebagaimana nampak dalam Tabel 4

Tabel 4

Distribusi Responden Berdasarkan Masa $\operatorname{Kerja}(\mathrm{n}=47)$

\begin{tabular}{llll}
\hline & & Frequency & Percent \\
\hline Valid & $<$ 5 Tahun & 32 & 68.1 \\
& 5 - 10 Tahun & 2 & 4.3 \\
11 - 20 Tahun & 4 & 8.5 \\
& $>$ 20 Tahun & 9 & 19.1 \\
Total & 47 & 100.0 \\
\hline
\end{tabular}

Sumber : Hasil Pengolahan Data Kuesioner

Pada tabel 4 di atas dapat dilihat bahwa jumlah responden yang lama bekerja kurang dari 5 tahun sebanyak 32 responden atau $68.1 \%$, bekerja 5 sampai 10 tahun sebanyak 2 responden atau $4.3 \%$, bekerja 11 sampai 20 tahun sebanyak 4 responden atau $8.5 \%$ dan bekerja lebih dari 20 tahun sebanyak 9 responden atau 19.1\%. Dengan demikian maka perawat yang bekerja di ruang Melati Rumah Sakit Husada sebagian besar lama bekerjanya kurang dari 5 tahun

Dalam penelitian responden terhadap variabel kepemimpinan dan kinerja perawat, menggunakan pengukuran skala likert dimana responden memberikan skor bervariasi mulai dari skor tertinggi 5 yang merupakan pernyataan sangat setuju, skor 4 setuju, skor 3 ragu-ragu, skor 2 tidak setuju dan skor 1 sangat tidak setuju, dibawah ini adalah hasil deskripsi penelitian terhadap masing masing variabel penelitian yaitu :

Variabel kepemimpinan terdiri dari lima (5) dimensi yaitu : (1) dimensi instruksi terdiri dari dua pertanyaan, (2) dimensi konsultatif terdiri dari dua pertanyaan, (3) dimensi partisipasi terdiri dari dua pertanyaan, (4) dimensi delegasi terdiri daru dua pertanyaan, dan (5) dimensi pengendalian terdiri dari dua pertanyaan, sehingga jumlah pertanyaan untuk variabel kepemimpinan sebanyak sepuluh pertanyaan.

Data kuesioner yang telah dikumpulkan kemudian dideskripsikan sehingga mempermudah dalam memahaminya. Hasil pengolahan data pada tabel di bawah ini merupakan penjelasan pengolahan dengan analisis deskripsi, yaitu: 
Tabel 5

Hasil Deskripsi Variabel Kepemimpinan $(n=47)$

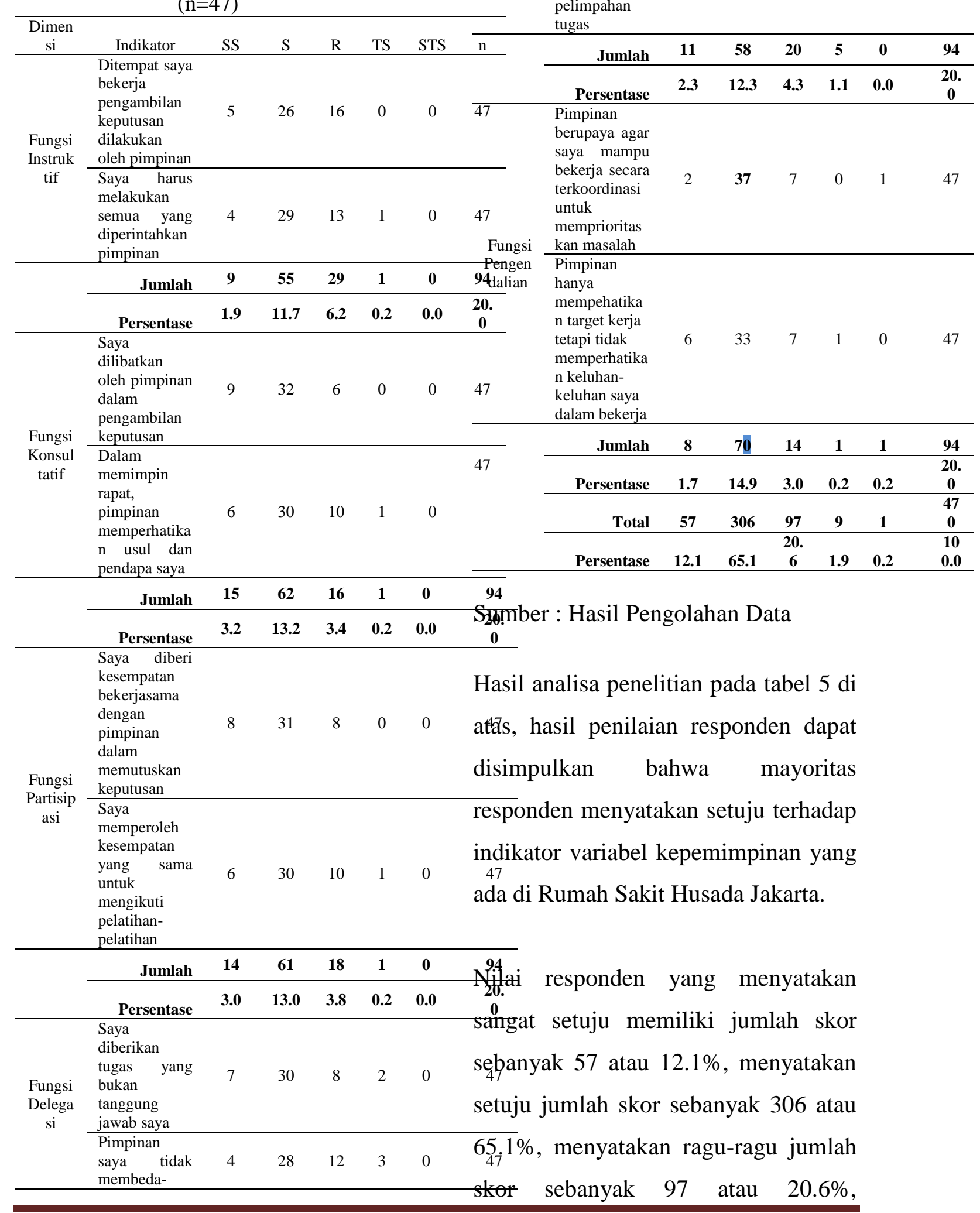

Jurnal Kesehatan Holistic/ Volume 4/ Nomor 1/Januari 2020

(ISSN: 2548-1843, EISSN: 2621-8704)

bedakan

dalam

memberikan

pelimpahan

Persentase

berupaya aga

bekerja secara

mempehatik

n target kerja

n keluhan-

memimpin 
menyatakan tidak setuju jumlah skor sebanyak 9 atau $1.2 \%$ dan menyatakan sangat tidak setuju jumlah skor sebanyak 1 atau $0.2 \%$.

Berdasarkan dimensinya, maka dimensi yang paling dominan pada variabel kepemimpinan adalah dimensi fungsi pengendalian, karena jumlah dan prosentase yang menyatakan setuju sebesar 70 atau $14.9 \%$, kemudian diikuti oleh dimensi fungsi konsultatif yang menyatakan setuju sebesar 62 atau 13.2\%, dimensi fungsi partisipasi yang menyatakan setuju sebesar 61 atau $13.0 \%$, dimensi fungsi delegasi yang menyatakan setuju sebesar 58 atau $12.3 \%$ dan dimensi fungsi instruktif yang menyatakan setuju sebesar 55 atau $11.7 \%$.

\section{KESIMPULAN DAN SARAN}

Berdasarkan hasil analisis yang telah dilakukakan maka kesimpulan yang diperoleh adalah terdapat pengaruh kepemimpinan terhadap kinerja perawat.

Hasil analisis regresi secara sederhana diperoleh nilai 0.972, artinya kepemimpinan memiliki pengaruh positif yang signifikan terhadap kinerja perawat. Jika gaya kepemimpinan mengalami peningkatan sebesar satu satuan maka kinerja perawat akan meningkat sebesar 0.972. Nilai $t_{\text {hitung }}$ sebesar 21.951 lebih besar dari nilai nilai $t_{\text {tabel }}$ sebesar 2.012 dan tingkat signifikansi 0.000, berarti Ha diterima, dengan demikian maka hipotesis penelitian pertama $\left(\mathrm{H}_{1}\right)$ dapat diterima atau terbukti. Kontribusi kepemimpinan terhadap kinerja perawat sebesar $91.3 \%$ sedangkan sisanya sebesar $8.7 \%$ dijelaskan oleh variabel lain yang tidak diteliti.

Pimpinan yang baik senantiasa menjaga pengaruh positif kepemimpinan yang telah menunjukan pengaruh baik terhadap kinerja perawat dengan mendelegasikan tugas kepada perawat tanpa membedabedakan dan dalam melaksanakan tugas selalu berkoordinasi dengan unit yang lain, atau bahkan dapat di tingkatkan lagi dengan cara meningkatkan kebijakan-kebijakan yang dikeluarkan, dan hendaknya pimpinan memperhatikan faktor-faktor 
lain yang juga mempengaruhi semangat kerja perawat.

Bagi penelitian selanjutnya, hasil kontribusi variabel yang diteliti menunjukkan masih ada variabelvariabel lain yang harus diperhatikan dalam penelitian ini. Penelitianpenelitian lebih lanjut, hendaknya menambah variabel lain seperti motivasi kerja, budaya organisasi, kompensasi, stress kerja dan lain-lain yang sekiranya dapat mempengaruhi kinerja perawat.

\section{DAFTAR PUSTAKA}

Adolf, Purba, (2006). Pengaruh Gaya Kepemimpinan, dan Motivasi Kerja Terhadap Kinerja Pegawai Negeri Sipil Pada Direktorat Jendral Perbendaharaan, Jakarta. Tesis Mahasiswa S2 UPI YAI.

Arikunto, (2003). Prosedur Penelitian

Suatu Pendekatan Praktek, Jakarta. Rineka Cipta
Dwi, Nugrahaeni, (2005). Pengaruh Gaya Kepemimpinan dan Komunikasi Terhadap Kinerja Karyawan Biro Kredit Bank Indonesia, Jakarta. Tesis. Mahasiswa S2 UPI YAI.

Edy, Sutrisno. (2009). Manajemen Sumber Daya Manusia. Jakarta. Kencana

Fakultas Ekonomi Universitas Persada Indonesia. (2010), Pedoman Penulisan Tesis Untuk Magister Manajemen, Jakarta Universitas Persada Indonesia Y.A.I.

Hadari, Nawawi. (2006). Kepemimpinan Yang Efektif. UGM Press. Yogyakarta

Hutapea, Parulian.. (2008). Kompetensi Plus. Jakarta PT Gramedia.

Miftah, Thoha. (2007). Penilaian Organisasi Konsep Dasar Dan Aplikasinya. PT Raja Grafindo Persada. Jakarta

Moeheriono, (2009). Pengukuran Kinerja Berbasis Kompetensi. Jakarta, Ghalia Indonesia. 
Onong, Uchjana (2009) , Ilmu

Komunikasi Teori dan Praktek.

Bandung, PT. Remaja

Rodakarya.

Palan, R. (2007). Competency Management. Seri Manajemen Sumber Daya Manusia. Jakarta Penerbit PM .

Ridwan. (2008). Cara Menggunakan Dan Memaknai Analisis jalur. Bandung. PT Alfabeta.

Rivai (2004). Kepemimpinan dan Perilaku Organisasi. Edisi Kedua. Jakarta. PT Raja Grafindo Persada.

Siagian, Sondang. (2001). Manajemen Sumber Daya Manusia. Yogyakarta, STIE YKPN.

Rochajat, (2008). Komunikasi Organisasi. Bandung,CV Mandar Maja.
Sopiah. (2008). Perilaku Organisasional. Yogyakarta. Penerbit ANDI.

Sugiyono (2011), Metode Penelitian Kombinasi, Bandung Alfabeta

Soekarso Iskandar Putong (2010). Teori Kepemimpinan. Mitra Wacana Media.

Soebagio Sastrodiningrat (2002) , Manajemen dan Kepemimpinan, Jakarta Kapita Selekta

Wirawan (2009), Teori Kepemimpinan Pengantar untuk Praktek dan Penelitian Jilid I dan II, Jakarta : Yayasan bangun Indonesia dan UHAMKA PRESS 